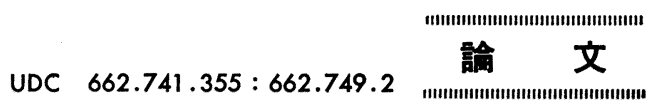

\title{
乾式消火コークスの品質向上要因*
}

\author{
美浦 義明** . 原口博***.西徹*** \\ 古牧 育男**** .小串 嘉宏****
}

\section{Factors Influencing Properties of Dry Quenched Coke}

\author{
Yoshiaki MiUra, Hiroshi Haraguchi, Tetsu Nishi \\ Ikuo KomakI, and Yoshihiro KogusHI
}

\begin{abstract}
Synopsis :
In order to determine the factors responsible for the improved properties of coke quenched by the USSR type of dry quencher, study was made by conducting quenching and reheating-cooling tests on the coke produced in a 1/4t-test oven and commercial ovens.

The tests showed that the following three factors are influential in property improvement while heat preservation in a pre-chamber is not related with property improvement:

1) As to chemical effect, unlike in wet quenching, water gas reaction does not occur in dry quenching, resulting in improvement of surface properties of coke.

2) As to heat effect, dry quenching lessens residual stress in coke lumps, resulting in improvement of internal properties of the coke.

3) As to mechanical abrasion effect, the structure of dry quencher serves to remove fragile parts from the coke.

Internal structure models of both dry-quenched and wet-quenched coke are illustrated in the paper.
\end{abstract}

\section{1. 緒言}

昨今のコークス炬を取り巻くきびしい環境規制と，オ イルショックを契機として高まつてきた省エネルギに対 する気運をうけて，八幡製鉄所戸畑第 2 コークス炉へ乾 式消火設備（以下 $\mathrm{CDQ}$ 設備と略記する）が設置され た. 本設備は, わが国における CDQ 設備の1号機とし て，テストプラント（公称 $56 \mathrm{t} / \mathrm{h}$ ) ではあるが昭和 51 年 2 月 2 日 稼動を開始し，以後順調な運転を続けてい る1) 3)

本設備は，ソ連 (Licensintorg 公団) からの導入技術 であるが，現在では日本鋼管（扇島, $70 \mathrm{t} / \mathrm{h} 5$ 基，昭和 51 年 9 月)4)，川崎製鉄（千葉，56 t/h 3 基，昭和 52 年 1 月)5)でも稼動しており，とくにり連に拈いては約 50 基, 年間 $20 \mathrm{Mt}$ のコークスを処理し6)，今後世界的に普 及する気運にあるといえよう。

$\mathrm{CDQ}$ 設備の設置目的は, 赤熱コークスの顕熱回収括 よび環境改善であるが，処理ュークスの品質が向上する
ことが知られており，戸畑コークス工場についても確認 されている2)3．ソ連では，品質について検討した報告も 多く見られる7) 11)が, いずれも品質向上の本質的要因に 関する検討は不十分である，そこで本報告では，湿式消 火扮よび乾式消火（以下 WQ および DQ と略記する) によるコークスの性状を比較するとともに，基礎実験を 行いCDQ コークスの品質向上に関する本質的要因につ いて検討した結果をのべる.

\section{2. 実験方針および方法}

\section{$2 \cdot 1$ CDQ コークスの品留に及ぼす要因の考え方}

$\mathrm{CDQ}$ コークスの品質は， 戸畑コークス工場の結果3) によれば，同一原料炭配合，同一乾留条件のもとで従来 の湿式消火コークスに比べ

1) 粒度分布は，より整粒状態になる。

2 ) 冷間強度は上昇 $\left(\Delta \mathrm{DI}_{15}^{150} \fallingdotseq 2, \mathrm{DI}_{60}^{150} \fallingdotseq 5\right)$

3 ）反応後強度は上昇（小型反応後強度で約 $2 \%$ )

4 ) 気孔率は約 $1 \%$ 低下

* 昭和 52 年 10 月本会講演大会にて発表 昭和 54 年 7 月 2 日受付 (Received July 2，1979)

** 新日本製鉄(株)生産技術研究所 工博 (Process Technology R \& D Laboratories, Nippon Steel Corp., 1-1-1 Edamitsu-cho Yawatahigashi-ku Kitakyushu 805)

*** 新日本製鉄(株)生産技術研究所 (Process Technology R \& D Laboratories, Nippon Steel Corp.)

**** 新日本製鉄(株) 八幡製鉄所 (Yawata Works, Nippon Steel Corp.) 
Table 1. Blending ratio of coal charge used* (\%).

\begin{tabular}{|c|c|c|c|c|c|c|c|}
\hline \multicolumn{4}{|c|}{ Hard coking coal } & $\begin{array}{l}\text { Good caking } \\
\text { coal }\end{array}$ & $\begin{array}{l}\text { Soft coking } \\
\text { coal }\end{array}$ & \multirow{2}{*}{$\begin{array}{l}\text { Slightly } \\
\text { caking coal }\end{array}$} & \multirow{2}{*}{ Anthracite } \\
\hline American & Australian & Canadian & Russian & Domestic & Australian & & \\
\hline 6 & 18 & 11 & 6 & 23 & 21 & 12 & 3 \\
\hline
\end{tabular}

* Sampled at Tobata coke plant, NSC

など，冷間および熱間性状とも改善されている，そこで これらの品質向上に及ぼす主要因を，CD Q 設備の構 造, 機能, 操業方法などから考え，つぎのように考え た.すなわち

1）乾式徐冷（注水しないことによる効果）

2 ) 機械的摩耗 (CDQ 設備内を降下中の摩耗効果)

3 ) Pre-chamber* 内の保熱（赤熱ュークス塊の温度 の均一化による効果)

また以上の直接要因のほかに，間接要因として

4 ) 石炭配合（装入炭配合構成，装入炭品質水準によ る効果)

5 ）コークス製造条件（装入炭事前処理，乾留条件な ぞの効果)

が考えられるが，本報では主として直接要因について検 討した．実験に際しては，できるだけ上述の各要因の効 果を分離しらるよう考慮した。

\section{$2 \cdot 21 / 4 t$ 試験用コークス炉を用いる実験}

同一配合，同一乾留条件下で WQ, DQ 両消火条件の 影響を比較するため, $1 / 4 \mathrm{t}$ 試験用コークス炬でコークス を製造した．主な条件はつぎのと扤りである.

1 ）装入炭：戸畑コークス工場（成型炭配合実施）の 装入炭（Table 1) を使用した。この装入炭（粉炭）の 一部に，結合剤として軟ピッチ $6.5 \%$ を添加して製造し た成型炭（ラショナル型 $27 \mathrm{cc}$ ）を 30\%（または 50\%） 配合した。 また比較のため粉炭のみを装入炭として使用 した。

2 ) 乾留条件 : $1 / 4 \mathrm{t}$ 試験炉（炉幅 $400 \mathrm{~mm}$, 炬長 $1200 \mathrm{~mm}$, 炉高 $1000 \mathrm{~mm})$, 装入炭水分 $4 \sim 8 \%$, 装入 密度 $0.83 \mathrm{t} / \mathrm{m}^{3}$ (粉炭の場合 $0.65 \sim 0.77 \mathrm{t} / \mathrm{m}^{3}$ ), フリュ 一温度 $1250^{\circ} \mathrm{C}$, 置時間 炭中温度 $950^{\circ} \mathrm{C}$ 上り $3 \mathrm{~h}$ 。

3 ) 消火方法 : 焼成コークスの半量を，水道水を注水 して冷却し WQ コークスとした. 残り半量を鉄板製の 箱へ入れ， $\mathrm{N}_{2}$ ガスを通じながら冷却 $(3 \sim 3.5 \mathrm{~h})$ し D Qュークスとした.

* C DQ設備はシャフト型であり，上部より赤熱コークスを供給するが 副生蒸気の安定供給をはかるためのバッファービンとしてPre-chamber が設けられている．とてでは，装入コークスの温度の均一化が行 われ冷却は行われない。

\section{$2 \cdot 3$ コークスの性状試験}

\section{$2 \cdot 3 \cdot 1$ 試料調製および一般性状試験}

$1 / 4 \mathrm{t}$ 試験炉で焼成したコークスおよび必要により採 取した実炉ュークス（WQ抽よ゙ CDQ）について,常法 にしたがつて各種の性状を調査した，この場合，試験炉 コークスについては消火直後のコークスのほかに，消火 直後のコークスをシャッター試験法12) にしたがつて 10 回落下処理したのち，塊 $(+25 \mathrm{~mm})$ と粉 $(-6 \mathrm{~mm})$ に 分離したもの，および一部の試料についてはマイカム試 験法 ${ }^{13)}$ そしたがつて処理したのち，塊 $(+25 \mathrm{~mm})$ 之粉 $(-6 \mathrm{~mm})$ に分離したものについても試験した。

測定した性状項目は，工業分析 ${ }^{14)}$ ，粒度 ${ }^{12) ， ト ゙ ラ ム ~}$ 度 ${ }^{12)}$ ，シャッター強度 ${ }^{12)}$, 反応性 ${ }^{12)}, \mathrm{CO}_{2}$ 反応後強度 (塊状試料を用いる方法15) 一大型反応後強度 $\mathrm{RDI}_{15}^{150}$ と略 記する一未よび中粒試料を用いる方法 ${ }^{16)}$ 一小型反応後強 度 $\mathrm{CSR} * *$ と略記する）である。またドラム強度につい ては， $\mathrm{DI}_{15}^{150}$ を摩耗強度， $\mathrm{DI}_{50}^{150}$ を塊の割れやすさを判 定する指数といら意味で潰裂強度と定義することにし た

\subsection{2 走査型電子影微鏡による表面観察}

$\mathrm{WQ}$ コークスの場合, 赤熱コークスへの注水によりコ ークス表層部で水性ガス化反応が起こることが予想され たので，走査型電子顕微鏡（以下 SEM と略記）により 表層部を観察した。

\section{$2 \cdot 4$ コークスの再加熱一冷却実験}

実炬コークス打よび $1 / 4 \mathrm{t}$ 試験炬 コークスにおいて は，試料粒度が任意であり，また消火条件の影響は試料 の粒度構成によつて変化することが予想された。 そこ で，純粋に粒度構成を揃えた試料について冷却方法の影 響を調べた。

実炉 CDQ コークス***を用い,カッター後における その粒度構成を基準にして $25 \sim 50 \mathrm{~mm} 30 \%+50 \sim 75 \mathrm{~mm}$ $70 \%$ の試料を調製し， $200 \times 470 \times 660 \mathrm{~mm}$ のステンレ 又製箱へ充填して（充填量約 $29 \mathrm{~kg}$ ) $\mathrm{N}_{2}$ 雾囲気中，電気 炬により加熱した。.Fig. 1 に示すヒートパターンで加熱

** Coke Strength after $\mathrm{CO}_{2}$ Reaction

*** 実好 C DQコークスは，WQコークスのように消火時の急冷衙撃を うけていないため, コークス塊内に角裂や残留応力が少ないと考え 


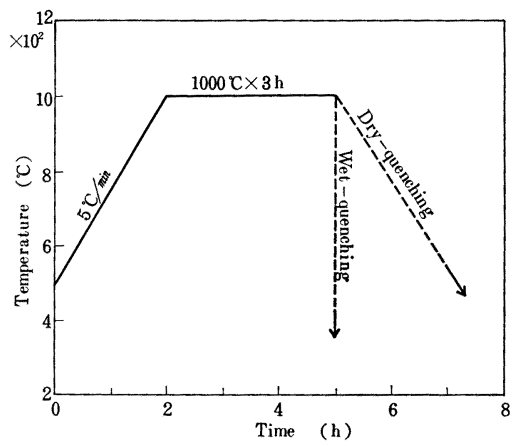

Fig. 1. Heating pattern in reheating-cooling test.

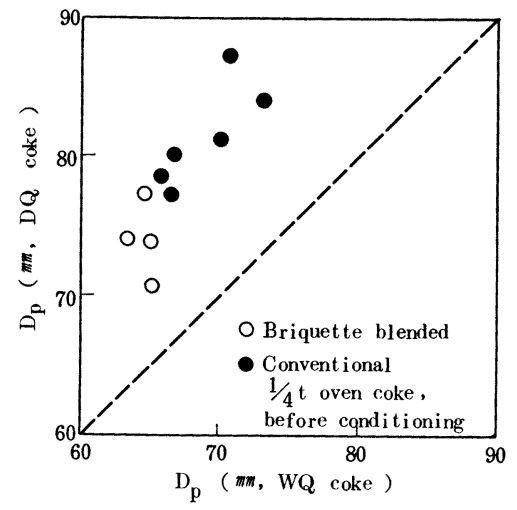

Fig. 2. Comparison of average coke size $\left(D_{p}\right)$ between $D Q$ and WQ coke.

後, WQの場合は試料を取出し水道水を注水して消火し た. DQの場合は，電気炉より箱を取出し $\mathrm{N}_{2}$ を流しな がら $200^{\circ} \mathrm{C}$ 以下になるまで邻却した. 以上のように処 理したコークスを，前述の場合に準じ各種の性状試験を 行つた.

\section{3. 結果ならびに考察}

\section{$3 \cdot 1$ 乾式徐冷の効果}

まず CDQ コークスが注水をらけない,すなわち乾式 徐冷といら消火方法のみの効果を明らかにするため, W Qおよび DQ 両ュークスの性状を比較した.

\section{$3 \cdot 1 \cdot 1$ 粒度}

1/4 t 試験炉で製造した WQ および $\mathrm{DQ}$ ュークスの 消火直後に括ける平均粒度を Fig. 2 へ示した. この結 果から，粒度は DQ コークスの方が大きいことがわか る. 試料粒度をそろえた場合の消火実験の結果を Table 2 に示したが，同様に DQ コークスの方が大きい。す なわち，DQコークスは注水急冷による熱衝撃をうけな いので，冷却過程でュークス塊内に発生する熱応力が少
Table 2. Comparison of coke size distribution between $D Q$ and WQ coke in reheating -cooling test.

\begin{tabular}{l|l|c|c|c}
\hline \multirow{2}{*}{ No. } & Sample & \multicolumn{3}{|c}{$\begin{array}{c}\text { Size distribution }(\%) \\
(n=3)\end{array}$} \\
\cline { 2 - 5 } & & $\begin{array}{r}\mathrm{mm} \\
\mathrm{mm}\end{array}$ & $\mathrm{mm}$ & \multicolumn{1}{c}{$\mathrm{mm}$} \\
& & 750.0 & 30.0 & 0 \\
\hline 1 & Original & 67.2 & 32.4 & 0.4 \\
2 & After dry quench & 67.9 & 35.9 & 0.2 \\
\hline
\end{tabular}

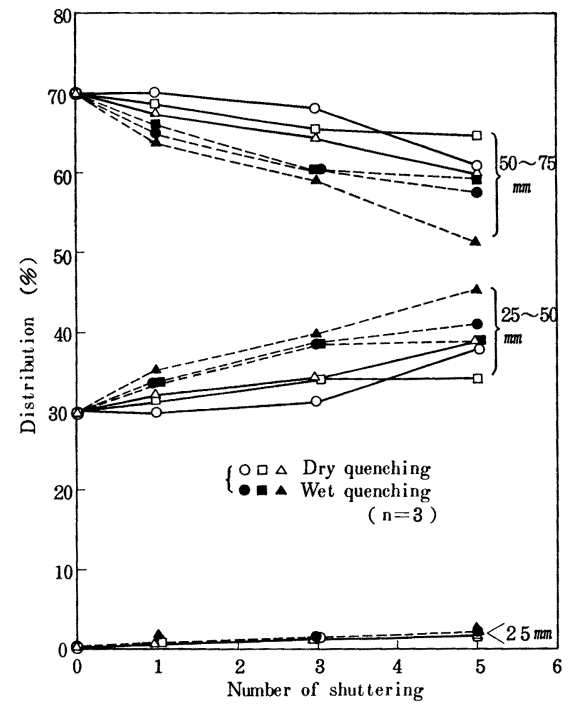

Fig. 3. Comparison of coke size distribution accompanying by shattering between DQ and WQ coke in reheating-cooling test.

ないため粒度が大きいものと推定される。

\section{$3 \cdot 1 \cdot 2$ 強度}

実用上の観点からシャッター強度, 摩耗強度および潰 裂強度の 3 種について検討した。

（1）シャッター強度

JIS の規定では，落下を 4 回くりかえし $50 \mathrm{~mm}$ また は $25 \mathrm{~mm}$ 以上の歩留りで示すことになつている10)が， ここでは，コークス塊内の残留応力やき裂の状態に差が. あれば，落下処理後のコークスの粒度分布に差が現わ れ，また乾式徐冷により残留応力やき裂は減少するとの 仮定のもとに検討したので，落下回数と粒度変化の関係 を追跡した.

まず，試料粒度をそろえて試験した場合の結果をFig. 3 に示した. この図から，DQコークスは落下回数の増 加とともに 50〜 75 mm の大塊の減少执よび 25〜 $50 \mathrm{~mm}$ の中塊の増加が，WQュークスの場合に比べて明らかに 小さい.すなわちシャッター強度は大きいことがわか 


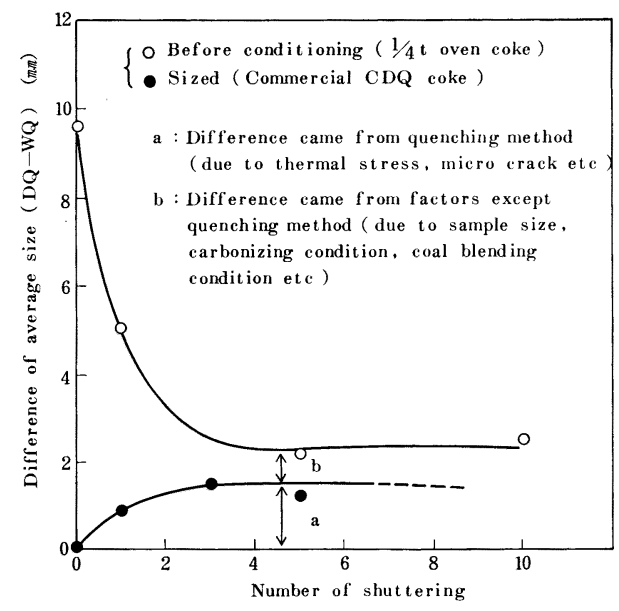

Fig. 4. Ghange of difference of average coke size accompanying by shattering.

る.また両コークスとも，<25 mm の小塊ないし粉の 発生量が非常に小さいことからみて，落下による粒度変 化は，消火時に生成したき裂や熱応力に起因する体積破 壊であることが推定される.

このように落下処理後の粒度分布に差が認められたの で，さきにのベたようにコークス塊内の残留応力やき裂 の寄与率すなわち, 純粋に乾式消火のみの効果を分離し て調べるため Fig. 4 に示すような検討を行つた. Fig. 4 は，縦軸に DQ および WQ コークスそれぞれの平 均粒度の差をとり，この值が横軸に示した落下回数とと もにどのように変化するかを，1/4t 試験炉コークス （粒度任意）および粒度をそろえたコークス（Fig. 3，実 炉 CDQ コークス)についてプロットしたものである. この結果からわかるように, 落下回数 5 回以上では両試 料における平均粒度の差はほぼ一定值を示している。ま た $1 / 4 \mathrm{t}$ 試験炉ュークスで実測された効果は $(\mathrm{a}+\mathrm{b})$ で 表され，このらち残留応力，き裂などの減少に基づく効 果（すなわち乾式徐冷の効果， a ）以外に，直接消火条 件に関係しない間接要因（試料粒度，乾留条件，原料配 合など）に基づく効果 (b) も存在することがわかる，乙 か乙乾式徐冷の効果 $(\mathrm{a})$ の方が大きい.

(2) 摩耗強度 (DI ${ }_{15}^{150}$ ) および潰裂強度 (DI $\left.{ }_{50}^{150}\right)$

Fig. 5 および Fig. 6 に $1 / 4 \mathrm{t}$ 試験炉コークスの場 合の結果をまた試料粒度をとろえた場合の試験結果を Table 3 に示した. これらの結果が示しているように， 摩耗強度については消火方法の影響はほとんど認められ ないが，潰裂強度については DQ ュークスはWQュー クスよりも大きい。これは耐摩耗性は，コークス炭素の 質の影響が大きいといわれており17)，乾式消火によつて

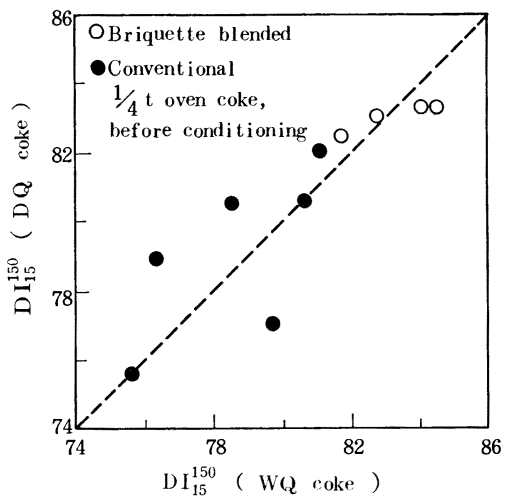

Fig. 5. Comparison of $\mathrm{DI}_{15}^{150}$ index between $\mathrm{DQ}$ and $\mathrm{WQ}$ coke.

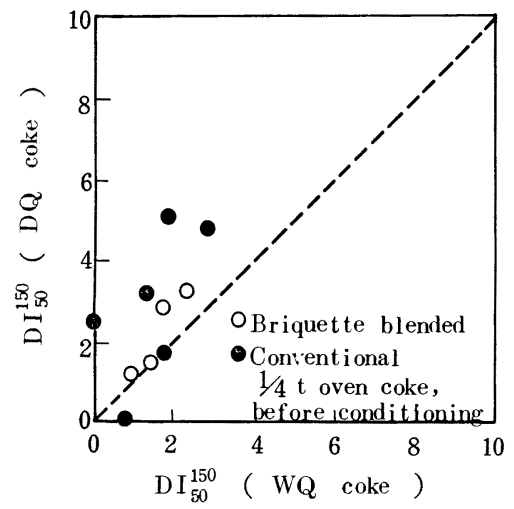

Fig. 6. Comparison of $\mathrm{DI}_{50}^{150}$ index between $\mathrm{DQ}$ and WQ coke.

Table 3. Comparison of $\mathrm{DI}_{15}^{150}$ and $\mathrm{DI}_{15}^{150}$ indicies between $D Q$ and WQ coke in reheatingcooling test.

\begin{tabular}{c|l|c|c}
\hline No. & \multicolumn{1}{|c|}{ Sample } & $\begin{array}{c}\mathrm{DI}_{15}^{150} \\
(n=3)\end{array}$ & $\begin{array}{c}\mathrm{DI}_{50}^{150} \\
(n=3)\end{array}$ \\
\hline 1 & Original & 84.5 & 18.3 \\
2 & After dry quench & 84.4 & 18.8 \\
3 & After wet quench & 84.3 & 14.1 \\
\hline
\end{tabular}

炭素自身の質が，摩耗強度へ影響するほどの变化を示さ なかったものと考えられる. ちなみにX線回折により黒 鉛化度を測定したが，両試料間でほとんど差は認められ なかつた。 また潰裂強度については，すでにのべたよう に乾式徐冷により塊コークス中の残留応力やき裂が減少 したためとみなされる.

\section{$3 \cdot 1 \cdot 3$ 反応性および反応後強度}

（1） 反応性（JIS 法）

JIS 法による反応性の測定結果を Fig. 7 にまとめて 


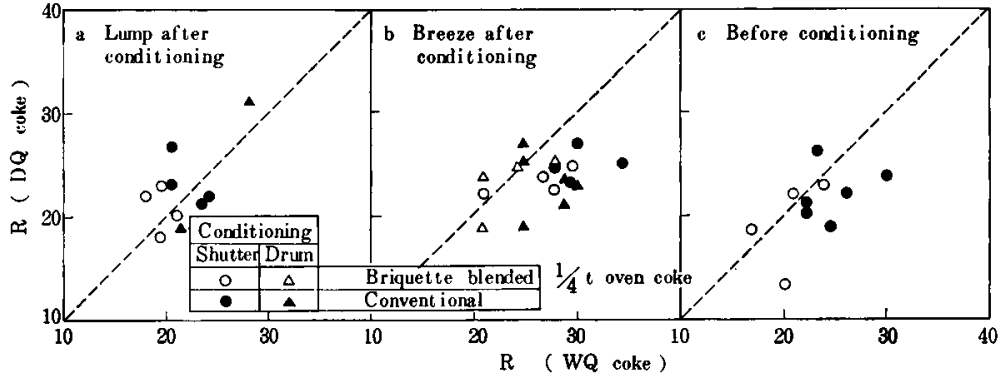

Fig. 7. Comparison of reactivity index ( $R, J I S$ method-AG) between $D Q$ and WQ coke.

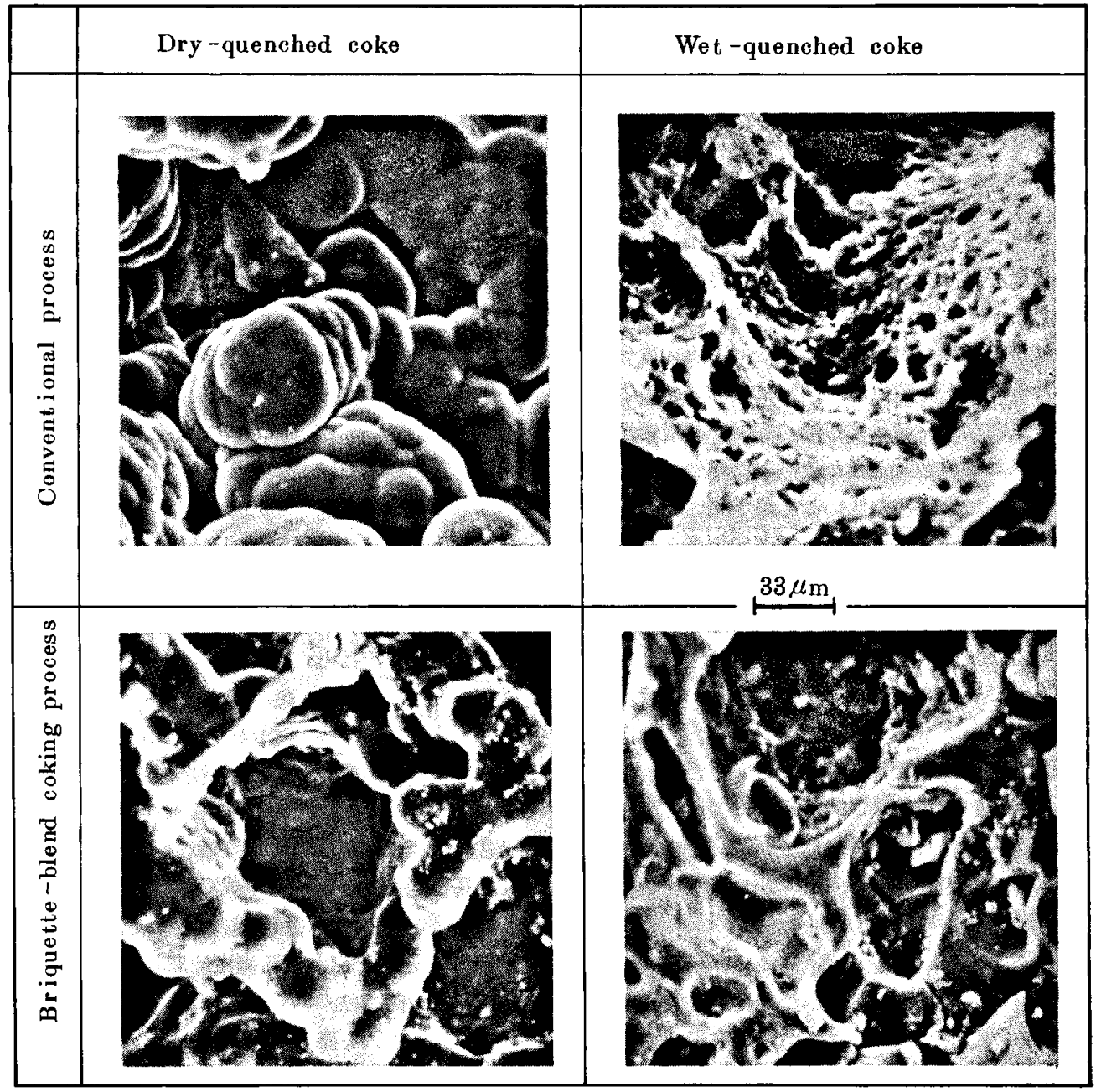

Photo. I. Scanning electron micrographs of surface of lump coke ( $1 / 4 \mathrm{t}$ oven coke).

示した．試料は，ンャッターまたはマイカムドラム処理 後の塊就よび粉，扣よび未処理平均試料について，それ
ぞれ DQ和よびWQコークスを比較した.ばらつきは 多少大きいが，つぎのようなことがわかる、すなわら， 
粉 (Fig. 7b) の場合は DQ コークスに比べ WQ コー クスの反応性がやや高くなつているが，塊（Fig.7a）で は差は認められない，平均試料では，粉の部分の影響を らけて WQ コークスの方がわずかに大きい傾向を示し ている. ここで, Fig.7b に示した粉には, シャッター 処理粉（焼成コークスケーキの脆弱な部分が主体）打よ びマイカムドラム粉（塊コークスの表層部摩耗粉が主 体）を含んでいるが，Fig. 7b の結果から両者は反応性 については，泳同等の性質をもつていると考兄られ る.

脆弱部コークスは，スポンジコークスなどを主体とし ており焼成温度が低いなどの条件により反応性が高いも のとみなされる。また表層部試料については，注水冷却 時に和汗る水性ガス化反応が考穴られる．これを確かめ るため，塊表層部をSEM で観察した結果を Photo. 1 に示した．この写真にみられるょうに，WQコークスの 表層部は水性ガス化反応により多孔質化して劣化してお り，そのため反応性が高くなつたものと考光られる．成 型炭配合コークスの場合は，コークスが緻密化している ので多少状況が異なるが，相対的傾向は粉炭装入の場合 と同様である。一方，DQ ュークスの表層部には球状組 織がみられるが，この成因については，石炭の乾留過程 で生成した一次タール蒸気が，すでに生成しているュー クス層のき裂面などを通過する際，表面に蒸着析出しさ らに炭化されたものと考学られる。したがつて，この球 状組織そのものは反応性の低いことが予想されるが，一 般に析出層の厚さは $\mu \mathrm{m}$ オーダーであると考学られる ${ }^{18)}$ ので，試料全体の反応性測定値にはほとんぞ影響してい ない.

\section{(2) $\mathrm{CO}_{2}$ 反応後強度}

塊状試料 $(25 \sim 100 \mathrm{~mm})$ を用いた場合の $\mathrm{CO}_{2}$ 反応後 強度 $\left(\mathrm{RDI}_{15}^{150}\right)$ を，常温に拁ける強度指数 $\left(\mathrm{DI}_{15}^{150}\right)$ と の関係で図示したのが Fig. 8 である.また，この場合 の $\mathrm{CO}_{2}$ との反応量を Fig. 9 に示した. 両図中，a は 消火後コークスそのままの試料について，またbはシャ ッター試験機で落下処理した試料についての 結果であ る.

これらの結果から，DQュークスは $\mathrm{WQ}$ ュークスよ りも $\mathrm{CO}_{2}$ 反応量が低く, したがつて反応後強度が高い ことがわかる．しかもシャッターで落下処理すると脆弱 部分が除かれるため*強度水準が上昇して打り，さらに 強度水準の高い成型炭配合コークスでは，DQ コークス

* シャッター試験機で落下処理すると試料粒度が小さくなるので，反 応量および反応後強度指数には試料粒度分布の影䅉が交絡している が，とこではDQおよびWQコークスの比較が目的であるので，そ のまま示した。

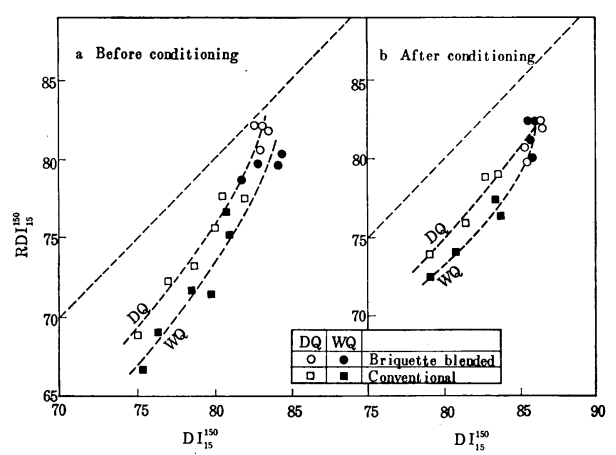

Fig. 8. Relation of $\mathrm{RDI}_{15}^{150}$ to $\mathrm{DI}_{15}^{150}$ of $1 / 4 \mathrm{t}$ oven coke.

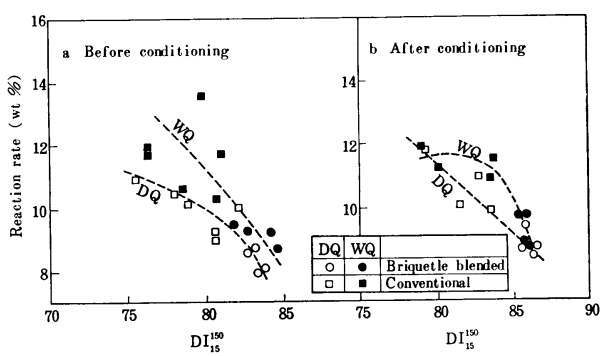

Fig. 9. Relation of reaction rate to $\mathrm{DI}_{15}^{150}$ of $1 / 4 \mathrm{t}$ oven coke.

そWQュークスの差はほとんどなくなつている.この傾 向は，対応する反応量の影響をそのまま反映している*.

つぎに, JIS 反応性（Fig. 7）の場合には，シャッタ 一で落下処理後の塊試料で DQ と WQ コークス間の 差がなかつたのに，Fig. 9 の場合には反応量に多少の 差を生じている．これは $\mathrm{CO}_{2}$ と反応させる場合の試料 粒度の相異に起因している.すなわち，WQコークスの 場合, 注水消火時 の急冷衝撃によつてコークス塊内に 熱応力やき裂が生成しているが，JIS 法では粉（0.84〜 $1.68 \mathrm{~mm})$ の状態で $\mathrm{CO}_{2}$ と反応させるので $\mathrm{DQ}$ コー クスとの差がほとんどなくなる．これに対してFig. 9の 場合は，塊 $(25 \sim 100 \mathrm{~mm})$ の状態で反応させるので塊 内の残留応力やき裂の差が $\mathrm{CO}_{2}$ 反応量や，さらに反応 後強度の差となつて現れたものと解积される.

\section{$3.2 \mathrm{CDQ}$ 設備における機械的摩耗の効果}

CDQ 設備では, 約 $30 \mathrm{~m}$ のシャフト型設備の頂部よ り赤熱コークスを降下させ，約 $4 \mathrm{~h}$ の滞留時間をるつて いる. したがつて，降下中に機械的摩耗を生じ製品コ一 クスに品質の変化が考学られる. 機械的摩耗の検討は, 実験室的再現実験が困難であるので，実炉におけるC D $Q$ および WQ コークスについて調查し，さらに比較 参考のため $1 / 4$ 試験炬ュークスをシャッター試験機また 


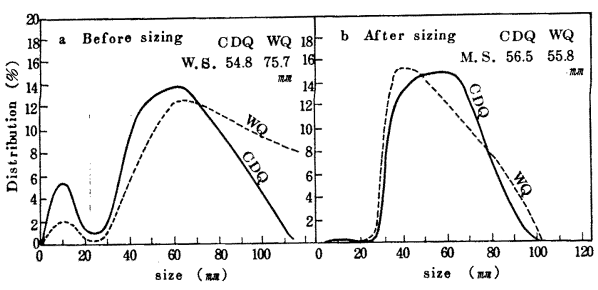

Fig. 10. Comparison of coke size distribution betwee CDQ and WQ coke at Tobata coke plant.

はマイカム試験機で処理したコークスについて調べた.

(1) 粒度

戸畑コークス工場 CDQ コークス（第2コークス炉） および WQ コークス（第 1 コークス炉: 第 2 コークス 炉と同一配合, 同一乾留条件, と它に成型炭 $30 \%$ 配 合）の粒度分布をを比較して Fig. 10 に示した. Fig. 10a はワーフ前または CDQ 排出後の試料, Fig. 10b は整粒後の高炉装入用製品コークスについてのデータで ある。これらの図からわかるように，CDQ ュークスは 排出後の状態では, WQ コークスよりも粒度が小さい が，整粒後ではやや粗粒でかつ粒度分布のそろつた結果 となつている。これは前項でのべたように，乾式徐冷の ためコークス塊内のき裂や残留応力が少ないので，コー クス塊が WQ コークスよりも機械的に安定であること に基づくものと考えられる.

つぎに Fig. 10a でも見られるように, CDQュークス は機械的摩耗の結果, 粉の発生が多いが, その後のハン ドリング過程での発生量は WQ コークスの場合よりも 少なく，製品としては安定なコークスであるといえる.

(2) 摩耗強度

上述のことから，CDQ 設備で赤熱ュークスを処理し た場合の機械的影響としては，摩耗による脆弱部の除 去と考えることができる。したがつて耐摩耗性を示す $\mathrm{DI}_{15}^{150}$ 指数は, Table 4 に示すように約 3 単位上昇して いる.また Table 4 には, WQ コークスを CDQ 設 備内を通過後処理*した結果を併記したが，この場合も 同様に約 2 単位の上昇を示している。 これらの結果は Fig. 11 に示すように，1/4t 試験炉ュークスをシャッ ター試験機で落下処理した場合についても確認すること ができた。

以上のことから, CDQ 処理によつてコークスの摩耗 強度が改善される機械的要因は，GDQ 設備内に拈ける 摩耗効果であると判断される。

* C DQ設備の修絽時を利用してWQコークスを $\mathrm{C} \mathrm{DQ}$ 設備へ充填し 下部から切り出してその強度を測定した.
Table 4. Change in $\mathrm{DI}_{15}^{150}$ index of commercial coke during CDQ treatment.

\begin{tabular}{c|c|c}
\hline Sample & $\begin{array}{c}\text { After quenching } \\
\mathrm{DI}_{15}^{150}\end{array}$ & $\begin{array}{c}\text { After passing } \\
\mathrm{CDQ}\end{array} \mathrm{DI}_{15}^{150}$ \\
\hline $\begin{array}{c}\text { Dry quenched } \\
\text { Wet quenched }\end{array}$ & $\overline{80.0}$ & 82.7 \\
\hline
\end{tabular}

Obtained by passing the WQ coke through GDQ equipment during the repairing term of equipment.

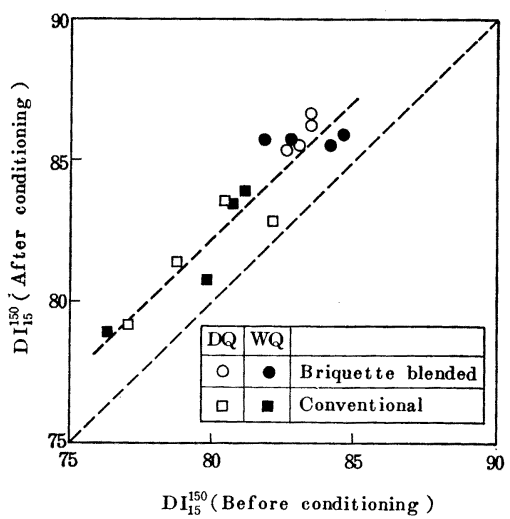

Fig. 11. Change in $\mathrm{DI}_{15}^{150}$ index of $1 / 4 \mathrm{t}$ oven coke by conditioning.

Table 5. Comparison of after-reaction strength $\left(\mathrm{RDI}_{15}^{150}\right)$ of commercial coke between CDQ and WQ coke at Tobata coke plant.

\begin{tabular}{l|c|c|c|c|c|c}
\hline & $\begin{array}{l}1976 \\
\text { Feb. }\end{array}$ & March & April & May & June & July \\
\hline CDQ coke & 81.6 & 81.1 & 81.0 & 81.7 & 82.2 & 81.1 \\
WQ coke & 79.4 & 79.2 & 78.4 & 78.7 & 78.3 & 77.8 \\
\hline
\end{tabular}

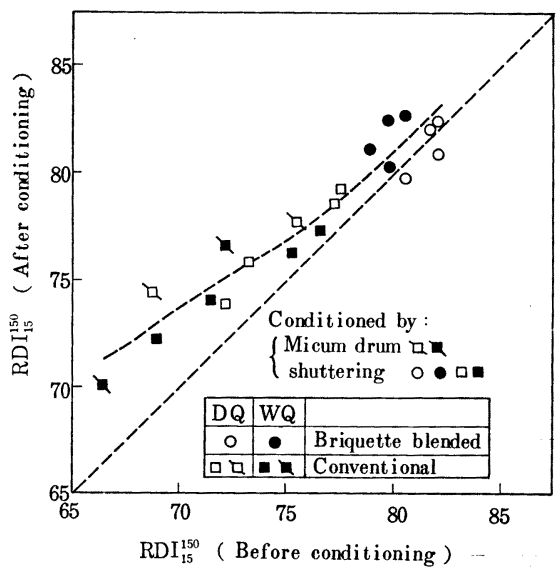

Fig. 12. Change in $\mathrm{RDI}_{15}^{150}$ index of $1 / 4 \mathrm{t}$ oven coke by conditioning. 


\section{(3) $\mathrm{CO}_{2}$ 反応後強度}

実炬コークス（戸畑コークス工場）に打ける大型反応 後強度 $\left(\mathrm{RDI}_{15}^{150}\right)$ の実測結果を Table 5 に示したが, $\mathrm{CDQ}$ コークスは WQ コークスに比べ $2 \sim 4$ 単位上昇 している.これらの值は, CDQ 処理による反応後強度 上昇のいわば総合值であるので，このうち機械的摩耗に 基因する分のみを分離するため, $1 / 4 \mathrm{t}$ 試験炉コークスに ついて求めた結果をFig. 12 亿示した。 この場合，焼成 コークスを消火したのち，シャッター試験機拈よびマイ カム試験機で処理した試料を用いた。この結果から，シ +ッター処理などによりコークスの $\mathrm{RDI}_{15}^{150}$ は上昇して おり，DQとWQュークス間では大差は認められない。 すなわち WQ コークスも脆弱部を除去すれば RDI ${ }_{15}^{150}$ は 上昇することがわかる. しかも, 試料コークスの強度水 準が高くなると上昇幅は小さくなつている，以上をまと めると, 機械的摩耗による $\mathrm{RDI}_{50}^{150}$ の上昇幅は約 1 単位 (摩耗前の試料コークスの $\mathrm{DI}_{15}^{150}>75$ の場合) であるこ とがわかる。

\subsection{CDQ 設備 Pre-chamber 内保熱の効果}

$\mathrm{CDQ}$ 設備の頂部に供給された赤熱コークスは，Prechamber 飞約 $1.5 \mathrm{~h}$ 滞留しこの間冷却は行われないの で，コークス炉内に㨃ける置時間延長と同じ効果, すな わちコークス塊の頭部〜尾部間の均一焼成効果がえら れることが予想される，そこで，戸畑コークス工場の GDQ 抽び WQ コークスについてコークス塊の頭〜 尾部間の各種性状指数を調査した（Fig. 13）が，両 コークス間でとくに差は認められなかつた. したがつて Pre-chamber 内保熱によるコークス品質の向上はほと んどないるのと判断される.

\subsection{CDQ コークスの品篗向上要因}

以上にのべた内容をまとめるとつぎのようになる.

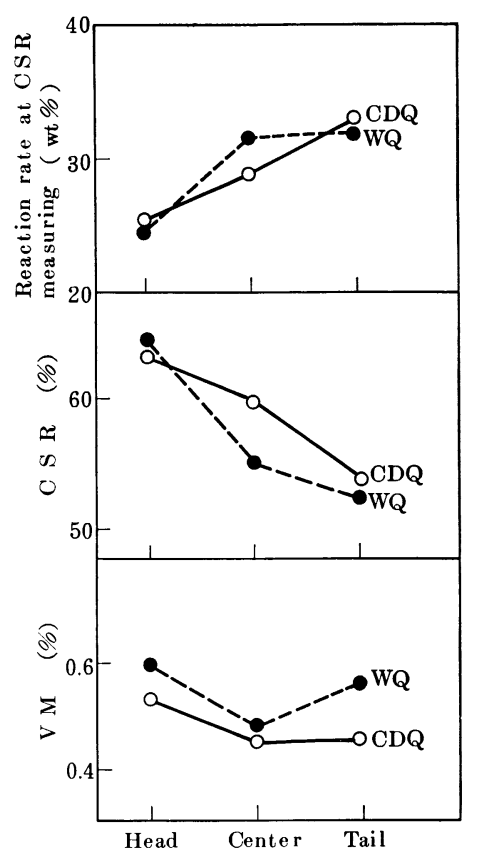

Fig. 13. Property of each part of a lump of coke.

（1）要因および効果

要因としては, 乾式徐冷および機械的スタビライジン グの 2 種類が考えられ, Pre-chamber での保熱はほと んぞ影響していない.これらの内容を Table 6 に示し た.すなわち，乾式徐冷については，さらに化学的効果 として水性ガス化反応が起らないことによる表面性状の 改善, および熱的効果として熱応力が少なくなることに よる内部性状の改善の 2 つにわけらる. 機械的スタビ ライジングについては, 摩耗による脆弱部分の除去効果 である。

そこで，これらの要因を考虑し CDQ 执よび WQ コ

Table 6. Summary of factors influencing upon the improvement of property of CDQ coke.

\begin{tabular}{c|c|c|c}
\hline No. & Factor & Physical/chemical reaction & Effectiveness \\
\hline 1 & $\begin{array}{l}\text { Dry slow quenching } \\
\text { 1) Chemical factor }\end{array}$ & $\begin{array}{l}\text { Water gas reaction does not } \\
\text { occur }\end{array}$ & $\begin{array}{c}\text { Improvement of surface property: } \\
\text { lower reactivity }\end{array}$ \\
\cline { 2 - 4 } & 2) Thermal factor & Thermal stress is reduced & $\begin{array}{l}\text { Improvement of inner property: } \\
\text { more uniform size distribution, } \\
\text { higher crushing strength and } \\
\text { lower reactivity. }\end{array}$ \\
\hline 2 & Mechanical stabilizing & Mechanical abrasion & $\begin{array}{l}\text { Rejection of fragile parts: } \\
\text { higher abrasion strength and } \\
\text { lower reactivity. }\end{array}$ \\
\hline 3 & $\begin{array}{l}\text { Retention in pre- } \\
\text { chamber }\end{array}$ & $\begin{array}{l}\text { Making temperature of lump } \\
\text { of coke uniform }\end{array}$ & \begin{tabular}{l} 
No effect. \\
\hline
\end{tabular}
\end{tabular}



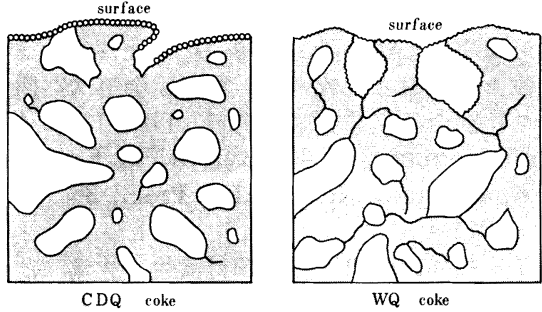

Fig. 14. Schematic drawings for the structure of $\mathrm{CDQ}$ and $\mathrm{WQ}$ coke.

一クス塊の内部構造を模式化して描いたのが Fig. 14 で ある.すなわち，CDQ コークス表面は球状組織で覆わ れて扣り閉気孔が多い.WQ コークスの表面は, 水性ガ ス化反応により球状組織が破壊され，またほとんどが開 気孔となり壁も多孔質化している.さらに塊内部では, $\mathrm{CDQ}$ コークスはき裂が少ないが，WQコークスはき裂 が多発しているものと推定される.

このような構造モデルを考えることにより, GDQ コ ークスと WQ コークスの各種性状の差を説明できる. すなわち，本報告ではすべての性状項目のデータを示さ なかつたが， CDQ ュークスは WQ コークスに対し

(1)粒度が整粒され，かつ大さい。

(2)潰裂強度, 摩耗強度, 反応後強度が高い。

(3)反応性が低い.

(4)揮発分が低い.

(5)真比重，見掛比重が大きい.

(6)気孔率が低い.

一方また当然のことながら，CDQ コークスは水分が低
くばらつきも少ない。

（2）品質向上要因効果の定量化の試み

Table 6 にまとめた各要因の効果を, 主な品質パラメ ータごとに定量的に把握することを試みた. コークス は, もつとも不均一な粒体の一つであり, その性状指数 測定值のばらつきは大きいので，データ解析にはかなり 大胆な単純化を行つた. すなわち，1/4 t 炉执よび実炉 コークスの 各消火法別試料に関する 測定值の 平均值を Table 7 へまとめて示したが，これらのデータについて Table 7 一併記したような考え方に従い，各効果を分離 して解析し，また本報に示した他のデータも参考にして Table 8 のような結果をえた. 結果の精度はともかくと して, この表から各要因の大略の寄与率および効果の程 度を知ることができる。

(3) 成型炭配合法に和ける CDQ 効果について

はじめにのべたように, 本報告では GDQ コークスの 品質向上に関する直接要因について検討したため，間接 要因の一つとして成型炭配合の効果についてはとくに触 れなかつた．しかし，実験データは各図表へ通常法（粉 炭装入）の場合と併記して示したので一言ふれたい.

CDQ を成型炭配合法に適用した場合の特徵として は，これまでの図表に示したよらに一般に通常法の場合 に拈ける CDQ の効果と同一の傾向を示す．ただし，同 一原料炭配合の場合，成型することにより製品コークス の品質レベルが上昇しているので，WQ〜 CDQ コーク ス間の品質差が小さくなる。一般に原料配合炭（または 生成コークス）の品質レベルが高くなると，コークス品 質向上のためにとられる各種アクションの効果が小さく

Table 7. Mean measured values for $1 / 4 \mathrm{t}$ and commercial oven coke with both quenching methods $(n=6 \sim 8)$.

\begin{tabular}{|c|c|c|c|c|c|c|}
\hline \multirow{4}{*}{$\begin{array}{l}\text { Property of } \\
\text { coke }\end{array}$} & \multicolumn{4}{|c|}{$1 / 4 \mathrm{t}$ oven coke } & \multicolumn{2}{|c|}{ Commercial oven coke } \\
\hline & \multicolumn{2}{|c|}{ Before conditioning } & \multicolumn{2}{|c|}{ After conditioning } & \multirow{2}{*}{ GDQ } & \multirow{2}{*}{$\begin{array}{c}\text { WQ } \\
\text { (After cutting) }\end{array}$} \\
\hline & $\mathrm{DQ}$ & WQ & DQ & WQ & & \\
\hline & a & b & c & $\mathrm{d}$ & e & $f$ \\
\hline $\mathrm{DI}_{15}^{150}$ & 81.2 & 81.0 & 83.4 & 83.5 & 85.5 & 83.5 \\
\hline $\mathrm{DI}_{50}^{150}$ & 2.6 & 1.6 & 3.3 & 1.5 & 30.9 & 19.9 \\
\hline $\mathrm{RDI}_{15}^{150}$ & 77.6 & 75.6 & 78.4 & 77.7 & 81.5 & 78.6 \\
\hline $\begin{array}{l}\text { Reactivity } \\
\text { index }\end{array}$ & 20.6 & 22.8 & 21.2 & 21.1 & $*$ & $*$ \\
\hline
\end{tabular}

* Not determined

Way of separation of each effect $a-b$ : chemical and thermal effect

c-d : thermal effect (chemical and mechanical effects disappear by conditioning) $c-a:$ chemical and mechanical effects $c-b$ : total effect $(\fallingdotseq \mathrm{e}-\mathrm{f})$ 
Table 8. Tentative estimation of effectiveness of factors influencing upon the improvement of property of GDQ coke.*

\begin{tabular}{|c|c|c|c|c|}
\hline $\begin{array}{l}\text { Parameter } \\
\text { concerned }\end{array}$ & $\begin{array}{l}\text { Chemical } \\
\text { effect }\end{array}$ & $\begin{array}{l}\text { Thermal } \\
\text { effect }\end{array}$ & $\begin{array}{l}\text { Mechani- } \\
\text { cal effect }\end{array}$ & $\begin{array}{l}\text { Total } \\
\text { sum }\end{array}$ \\
\hline $\mathrm{DI}_{15}^{150}\left(\begin{array}{l}(\%) \\
(-)\end{array}\right.$ & $\begin{array}{l}0 \\
0\end{array}$ & $\begin{array}{l}0 \\
0\end{array}$ & $\begin{array}{l}100 \\
2.0\end{array}$ & $\begin{array}{l}100 \\
2.0\end{array}$ \\
\hline $\mathrm{DI}_{50}^{150}(\stackrel{(\%)}{(-)}$ & $\begin{array}{l}0 \\
0\end{array}$ & $\begin{array}{r}100 \\
2 \sim 10\end{array}$ & $\begin{array}{l}0 \\
0\end{array}$ & $\begin{array}{c}100 \\
2 \sim 10\end{array}$ \\
\hline $\operatorname{RDI}_{15}^{150}(\%)$ & $\begin{array}{l}46 \\
1.3\end{array}$ & $\begin{array}{l}24 \\
0.7\end{array}$ & $\begin{array}{l}30 \\
1.0\end{array}$ & $\begin{array}{l}100 \\
3.0\end{array}$ \\
\hline $\begin{array}{l}\text { Reactivity } \\
\text { index } \\
\qquad(\%) \\
(-)\end{array}$ & $\begin{array}{l}100 \\
2\end{array}$ & $\begin{array}{l}0 \\
0\end{array}$ & $\begin{array}{l}0 \\
0\end{array}$ & $2^{100}$ \\
\hline
\end{tabular}

* upper figure : relative value, lower figure : absolute value

なることが経験的に知られているが，CDQ の効果につ いてもほぼ同様に考えて差支えないであろう。

\section{4. 結言}

ソ連式乾式消火設備で処理されたコークスの品質向上 要因について, $1 / 4 \mathrm{t}$ 試験コークス炬扤よび実炍ュークス の再加熱一消火実験をべースとして検討し，またその結 果に基いて CDQ おょび WQ コークス塊の構造モデル を提示した．今後 $\mathrm{CDQ}$ 処理は, 省エネルギ，環境対策 などの点からますます普及するであろらが，その際，処 理コークスの品質向上およびュークス生産の経済性を高 めて行くために，さらに原料石炭配合や事前処理との有 効な組合せ効果の解明が重要であろう.

\section{交献}

1) 野口信雄: 鉄鋼界, 昭和 51 年 6 月, p. 46

2 ）佐々木富雄, 古牧育男: 燃料協会第 62 回コーク 又特別会研究発表講演要旨, (1977), p. 62

3 ) $N$. Noguchi, M. Kobayashi, Y. Kogushi, and $K$. Katsuno: Ironmaking Proc., 36 (1977), p. 271

4 ) 伊沢哲夫, 岡田 豊, 藤村武生, 大橋 茂: 日本 鋼管技報，（1978）76，p. 1

5 ) 高橋 裕, 百合野貴之, 中本 毅：川崎製鉄技報 10 (1978) 2，3，p. 248

6 ) B. Rogan: Iron and Steel International, 51 (1978), p. 101

7 ) P. S. Akulov, I. M. Lazovskil, E. $M$. Shreider, $M . S$. Krughinin, and $I$. $S$. Elkind: Coke and Chem. USSR, (1968) 9, p. 18

8 ) $M . S$. KRUGHININ: 同上, (1970) 6, p. 19

9 ) $M . G$. Sklyar, L. P. Semisalov, I. V. Syterko, $D$. D. Vorobev, and V.G. Balanov: 同上, (1971) 10, p. 24

10) Yu. S. Karabasov, $A . N$. Pokhvisner, $A . I$. Isteev, and $E$. $M$. Voropaev: Steel in the USSR, (1972) 11, p. 854

11) M. M. Kovalevskaya and $V . I$. Borsuk: Coke and Chem., USSR, (1973) 7, p. 23

12) JIS K 2151-1972 コークス類の試験方法

13) ISO R 556-1967 Determination of the Micum indicies of coke

14) JIS M 8812-1972 石炭類およびュークス類の工 業分析方法

15) 井田四郎, 西徹, 仲摩博至: コークスサーキ ニラー, 21 (1972), p. 252

16) 村上昭三, 原 義明, 石川 功：コークスサーキ ニラー, 23 (1974), p. 82

17) $R$. Loison, $P$. Foch, and $A$. Boyer: Le Coke, (1970), p. 178 [Dunod]

18）井田四郎，奥原捷晃，山口徳二：鉄と鋼，59 (1973), S 12 